\title{
First Report of Powdery Mildew Caused by Erysiphe aquilegiae on Columbine in the United States
}

Michael Bradshaw ${ }^{\dagger}$, University of Washington, Center for Urban Horticulture, School of Environmental and Forest Sciences, Seattle 98195

Accepted for publication 30 January 2018.

Columbine (Aquilegia sp., Ranunculaceae) is a late summer to fall flowering ornamental. Powdery mildew was collected from columbine plants growing outdoors in the botanical garden at the Center for Urban Horticulture, University of Washington, Seattle $\left(47.65^{\circ} \mathrm{N} ; 122.29^{\circ} \mathrm{W}\right)$ in October 2016 . At least one powdery mildew colony was present on each leaf of the infected plants. Fungal colonies were circular, dense, white, and covered the surface of infected leaves (Fig. 1). Immediately after noticing signs of powdery mildew, cuttings of noninfected plants were established in the Douglas Greenhouse at the University of Washington. Temperatures in the greenhouse during this time ranged from 20 to $22.2^{\circ} \mathrm{C}$ with a relative humidity between 30 and $60 \%$. A pathogenicity test was conducted once by rubbing the infected leaves onto the leaves of two healthy plants. Each of these originally healthy plants developed signs of powdery mildew. Two different Aquilegia sp. plants were left in a separate room and served as controls. None of the control plants developed signs of powdery mildew. Signs on the newly infected plants were first observed 6 days postinoculation. Signs on artificially infected plants were identical to those observed on naturally infected plants with leaves becoming covered by mycelia. Chlorotic and necrotic symptoms were noted, followed by premature leaf senescence. Conidia were hyaline, ellipsoid, lacked fibrosin bodies, and formed in chains of three to five. Conidia $(n=10)$ measurements ranged from 29.3 to $40.4 \mu \mathrm{m}$ long (average $33.1 \mu \mathrm{m}$ ) by 13.2 to $20.3 \mu \mathrm{m}$ wide (average $16.5 \mu \mathrm{m}$ ). Conidial length-to-width ratio ranged from 1.6 to 2.7 (average 2.1). Conidiophores occurred unbranched with cylindrical foot cells $(n=5)$ that ranged from 51.0 to $99.1 \mu \mathrm{m}$ long (average $72.9 \mu \mathrm{m}$ ) by 5.6 to $11.6 \mu \mathrm{m}$ wide (average $8.7 \mu \mathrm{m}$ ). Zero to two cells occurred between the foot cells and conidia. Foot cells $(n=5)$ ranged from 21.2 to $38.1 \mu \mathrm{m}$ long (average $27.7 \mu \mathrm{m}$ ) by 7.7 to $12.2 \mu \mathrm{m}$ wide (average $9.3 \mu \mathrm{m})$. Germ tubes $(n=10)$ were simple with an average width of $5.5 \mu \mathrm{m}$ (Fig. 2). Appressoria were unlobed and indistinct. Chasmothecia were not observed. Morphological characteristics of the fungus were consistent with those of Erysiphe aquilegiae (Braun and Cook 2012).

To confirm species identification, the internal transcribed spacer (ITS) gene region of rDNA was amplified with the primers ITS4/ ITS6 (White et al. 1990). A BLASTN search of the E. aquilegiae isolate (MF278271) showed $>98 \%$ similarity with E. aquilegiae from Clematis stans in Japan (LC009944). Based on morphological and molecular characteristics, it was concluded that the powdery mildew fungus was E. aquilegiae DeCandolle. To the author's knowledge this is the first unequivocal report of $E$. aquilegiae occurring within the United States (Farr and Rossman 2017). These results are important for the U.S.

${ }^{\dagger}$ Corresponding author: Michael Bradshaw; E-mail: mjb34@uw.edu

(C) 2018 The American Phytopathological Society floral industry, for which Aquilegia is a major crop. This disease can compromise the esthetic value of Aquilegia sp. by reducing the plant's floral output and stunting its growth.

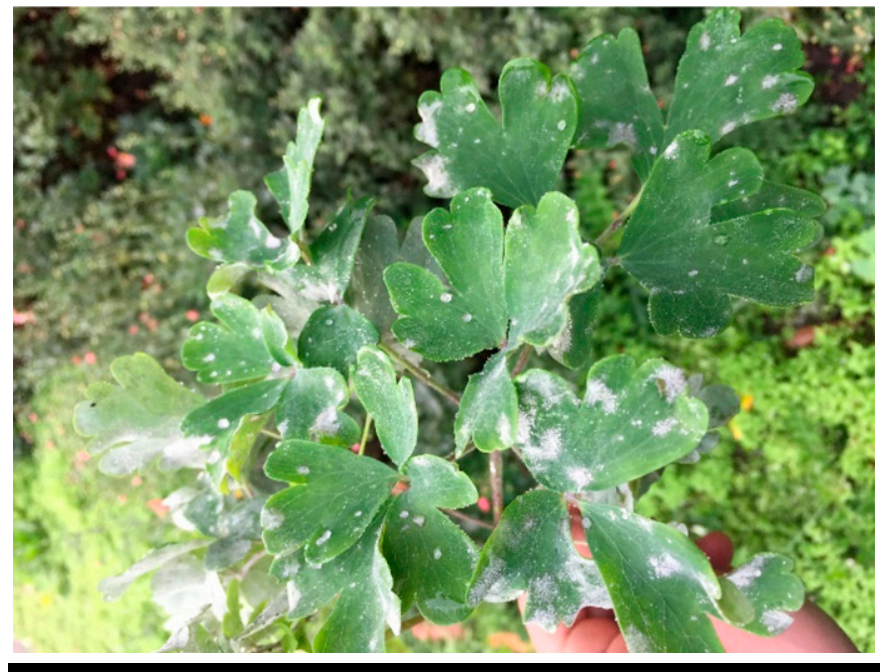

FIGURE 1

Signs of powdery mildew on columbine.

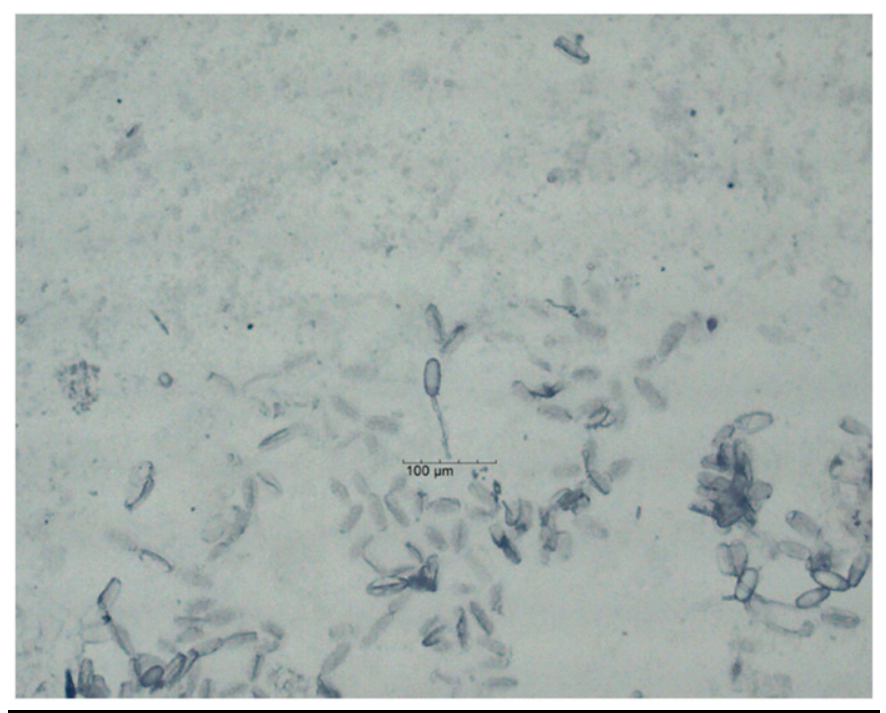

FIGURE 2

Conidia with germ tube under a compound microscope. 


\section{Literature Cited}

Braun, U., and Cook, R. T. A. 2012. Taxonomic Manual of the Erysiphales (Powdery Mildews), CBS Biodiversity Series 11. CBS, Utrecht, the Netherlands.
Farr, D. F., and Rossman, A. Y. 2017. Fungal Databases, Syst. Mycol. Microbiol. Lab., ARS, USDA. Retrieved January 13, 2017, from https://nt.ars-grin.gov/fungaldatabases/ White, T. J., Bruns, T., Lee, S., and Taylor, J. 1990. Amplification and direct sequencing of fungal ribosomal RNA genes for phylogenetics. Pages 315-322 in: PCR Protocols: A Guide to Methods and Applications. M. A. Innis, D. H. Gelfand, J. J. Sninsky, and T. J. White, eds. Academic Press, San Diego, CA. 